\title{
Correlates of Secret Multiple Partnership within Stable Relationships, Sex Differentials and HIV Risk amongst Tiv People of North Central Nigeria
}

\author{
Timiun Godwin Aondohemba ${ }^{1,2^{\star}}$ \\ ${ }^{1}$ Australian Catholic University, 115 Victoria Parade, Fitzroy Vic 3065, Melbourne, Australia. \\ ${ }^{2}$ Department of Sociology, Benue State University, Makurdi, Benue State, Nigeria.
}

Author's contribution

The sole author designed, analyzed and interpreted and prepared the manuscript.

Article Information

DOI: $10.9734 / I S R R / 2017 / 32577$

Editor(s):

(1) Gabriella G. D. D'ettorre, Department of Public Health and Infectious Diseases, University of Rome "Sapienza" and Azienda Policlinico Umberto I, Italy. Reviewers:

(1) Abiodun Adeniran, University of llorin, Nigeria (2) Abdulkarim Garba Mairiga, University of Maiduguri, Nigeria. (3) Md Ashlesha Kaushik, Children's Hospital, India. Complete Peer review History: http://www.sciencedomain.org/review-history/19997

Original Research Article

Received $3^{\text {rd }}$ March 2017

Accepted 11 $1^{\text {th }}$ May 2017

Published 11 ${ }^{\text {th }}$ July 2017

\section{ABSTRACT}

Background: Despite the consensus in both the developing and developed countries that concurrent multiple sexual relationship is unsafe sexual behaviours; gaps exist in knowledge with regard to the dynamics of secret multiple partnership within stable relationships that account for over $40 \%$ new HIV infection in Nigeria. This study examines the correlates of secret multiple partnership within stable relationships, sex differentials and HIV risk amongst Tiv people, Nigeria. Methods: A sample of 1,621 (864 women; 757 men; 815 HIV seropositive; 806 HIV seronegative) respondents who participated in survey and in-depth interviews were selected from 2 clinics and 2 other locations using multi-stage and purposive sampling methods. SPSS (version 21) was used for quantitative data analysis.

Results: Approximately $38 \%$ men and women who are married have reported being aware of their partners' secret sexual relationships. Fifty three percent women and $46.2 \%$ men who are aware of their partner's secret relationships are HIV positive. The correlates vary, but the common factor associated with both men and women whose partners are engaged in secret relationships is partners' absence from home for a longer period. Married men are more likely to engage in secret multiple partnerships than their female counterpart. 
Conclusion: Information on correlates of secret multiple partnerships and HIV risk in stable relationships could be of considerable benefits for developing strategies for HIV prevention through secret multiple sexual relationships that are shrouded in unsafe sexual practices, especially in Nigeria and Africa at large where secret multiple partnerships are common but condom use is low.

Keywords: Sex differentials; secret multiple relationships; stable relationships; correlates; HIV; Africa.

\section{INTRODUCTION}

Secret sexual relationship refers to a sexual behaviour where an individual keeps a stable relationship such as marriage or cohabitation but clandestinely engage in other relationships due to contextual factors. It is a form of concurrent partnerships. Generally, concurrent multiple sexual relationships have been identified as unsafe sexual behaviours in both the developing [1] and developed countries [2]. The phenomenon first came to prominence when scholars posited that multiple concurrent partnership could be a driving force for the spread of HIV in Africa [1,3-6] and other regions of the world, especially where multiple partnership is acceptable form of marriage or sexual relationships amongst groups [7]. Multiple concurrent sexual partnerships which exist in Nigeria and elsewhere can be amongst legally married individuals (polygamy) or other socially acceptable relationships such as cohabitation. The secret sexual relationship may occur where a member of the stable union clandestinely keeps another sexual relationship. Both men and women have been observed to indulge in multiple concurrent sexual relationships [8]. However, gaps exist in knowledge on the phenomenon of secret multiple sexual relationship as a type of concurrency practiced amongst stable relationships. This study examines the sex differentials, correlates and risk of HIV infection through secret multiple sexual relationships amongst the Tiv people of Central Nigeria. The aim is to provide knowledge that would be useful for preventing HIV infection through secret multiple partners in stable relationships in Nigeria.

Motivated by the apparent increase in the spread of HIV in Africa, Watts and May [3] simulated a mathematical model describing how concurrent partnerships could aid the spread of HIV. Subsequently, similar views were expressed by other scholars who examined concurrent sexual relationships $[4,9,10,11]$. However, Reiners and Watkins [12] have suggested that concurrency in polygyny is negatively correlated with the spread of HIV, while Kretzscmar, White and Careal [8] have called for differentiation between types of concurrency.

It can be argued that sex work is a type of concurrency, hence it is practiced amongst multiple concurrent partners. Such sexual behaviours have been observed to be highly risky especially where condom usage is low. Thus, it (sex work) has attracted considerable attention [13-18]. Serial partnerships with short gaps between them may constitute similar risk such as posed by multiple concurrent partners, since a recently infected person may expose a new partner to HIVISTI while transmission probabilities are highest [19].

Related studies conducted amongst Garı 'funa men suggest that concurrent or even polygamous partnerships was common, even though infidelity was not universally acceptable practice within the society or primary female partners $[20,21,22]$. Other mixed methods studies indicate that Garı 'funa men and women in Honduras keep multiple or concurrent sexual partners, though these practices remain more socially permissible [21].

Further, in Nairobi married women living in the slums were at least three times as likely to have multiple sexual partners as their rural counterparts [23]. Similarly, women in Uganda [16] and those in South Africa [24,25] within cultural ambit were engaged in multiple concurrent partnerships.

The phenomenon of secret concurrent partnerships may have profound effect on groups such as married individuals or other stable relationships (cohabitation). Understanding secret multiple partnership would help in differentiating between benign and risky multiple partnerships as suggested by Kretzscmar, White and Careal [8]. Furthermore, information on sex differentials in secret partnerships may be a veritable tool for HIV prevention policies in areas where incident rates of infection are still high; for example, in Nigeria where the National Agency for the Control of HIVIAIDS [26] has reported that $42 \%$ of new infections are from individuals who 
are considered to be in 'low risk' sexual relationships such as those in marital or cohabitation unions.

\section{METHODS}

\subsection{Theory}

The study has utilised sexual webs model [27] for the explanation of secret multiple partnerships amongst the Tiv people. On the universal scale, the men have more sexual capacity (favourable individual, family and structural factors) for initiation of relationships and sexual performance than the women. However, in some instances, the women may possess enhanced sexual capacity from gainful activity or/and peer support to determine issues in relationships, hence they engage in secret multiple sexual relationships, despite the social norms proscribing women from having more than one sexual partner at a given time. Whereas the men may utilise their capacity to keep secret relationships in order to satisfy their desire to experience variety in sexual acts and also father children, the women are motivated to keep secret relationships as retaliatory measures against their partners, who have indulge in the behaviour, and to satisfy unmet needs including sexual satisfaction. Hence men and women alike indulge in secret concurrent sexual relationships. Some Individuals who for certain reasons stay away from home for a longer period of time of at least 3 months are motivated to engage in secret sexual relationships.

\subsection{Quantitative Methods}

The multi-stage sampling method was used in selecting 1,601 respondents in four different locations $^{a}$ (Mkar, Aliade, Udei and Jovkyundan which are towns and villages from Gboko, Gwer, Guma and Konshisha Local Government Areas of Tivland respectively). An eight page questionnaire with closed and open ended questions (on background characteristics, risky sexual behaviours, structural factors and HIV) was used for data collection in the first stage. Face to face interviews were conducted with the respondents by the researcher (author), with the aid of some research assistants. The questionnaires were pretested by conducting a mock data collection with 50 respondents before the actual data collection exercise. The internal consistency and reliability of the data collection instrument was very high. The quantitative data collection lasted for five months between April and August, 2014. Completed questionnaires were scrutinised in the field to ensure exactness of the recorded information. Thereafter, they were retrieved and stored in a well secured office, accessed by the researcher alone.

At the completion of data collection, the responses were coded and entered into Statistical Product and Service Solution (SPSS) version 21 software, which has provision for the Generalised Linear Regression with Cumulative Link, was used for the analysis of quantitative data [see 14].

\subsection{Qualitative Methods}

In this segment of data collection, purposive sampling was used in selecting 20 respondents who participated in in-depth interviews. Five individuals were selected in each location. The interviews were conducted in Tiv language using a guide with questions on structural factors, and background characteristics influencing sexual behaviours. An audio recorder was used for recording the discussions during the in-depth interviews for the purpose of transcription after the data collection sessions. The data were transcribed and analysed by the researcher. The findings from qualitative data provided further insight into the intricacies of illicit sexual behaviours.

\subsection{Ethical Issues}

Application for Ethics clearance was sent to Australian Catholic University (ACU) human research ethic committee (HREC), and Ethics approval was given in March, 2014. The researcher has adhered completely to the ethical provisions of both the University and other regulatory bodies (Nigeria) involved in overseeing research conducted involving human beings. The Ethics clearance from ACU was accepted by the Benue State University Ethics Committee for the conduct of this study. The research was conducted with integrity noting its responsibilities to all stakeholders. Both the consent to participate in the study and for the publication of the findings was obtained from the participants using ACU consent form before data collection activities.

\section{FINDINGS}

The phenomenon of secret multiple partnerships is common amongst those who are married, cohabiting, single, widowed, separated and divorced (see Table 1). 
Table 1. Percentage distribution of relationship status by awareness of partner's secret sexual relationship

\begin{tabular}{lllll}
\hline Relationship status & \multicolumn{4}{c}{$\begin{array}{c}\text { Awareness of secret } \\
\text { relationship }\end{array}$} \\
\cline { 2 - 5 } & \multicolumn{3}{c}{ Women } & Men \\
\cline { 2 - 5 } & Yes & No & Yes & No \\
\hline Married & 37.9 & 65.6 & 38 & 54 \\
Single & 48.1 & 28.0 & 31 & 31 \\
Widowed & 5.7 & 1.9 & 15.5 & 8.8 \\
Divorced & 4.2 & 1.0 & 7.8 & 3.1 \\
Separated & 3.8 & 3.1 & 6.6 & 3.3 \\
Cohabiting & 0.4 & 0.4 & 1.1 & 0.0 \\
N & 264 & 485 & 361 & 491 \\
$\%$ & 100 & 100 & 100 & 100 \\
\hline \multicolumn{2}{c}{ Note. The source of data is from field survey, 2014 }
\end{tabular}

The women are more likely to keep either one $(61.2 \%$ vs $38.8 \%)$ or two sexual partners $(54.9 \%$ vs $45.1 \%$ ) than the men, while the men are more likely to keep more than 2 sexual partners than the women (56.2\% vs $43.8 \%$; See Table 2 ).

Table 2. Percentage distribution of respondents' sex by number of sexual partners

\begin{tabular}{lllll}
\hline \multicolumn{5}{c}{$\begin{array}{c}\text { Number of sexual partners } \\
\text { kept by the respondents }\end{array}$} \\
\hline Sex & One & Two & More than 2 & $\mathbf{N}$ \\
Male & 38.8 & 45.1 & 56.2 & 749 \\
Female & 61.2 & 54.9 & 43.8 & 852 \\
Total & 289 & 903 & 409 & 1601 \\
$\%$ & 100 & 100 & 100 & \\
\hline \multicolumn{5}{c}{ Note. The source of data is from field survey, 2014 }
\end{tabular}

Table 3. Percentage distribution of respondents by awareness of partners' secret relationship and HIV status

\begin{tabular}{lccc}
\hline \multicolumn{3}{c}{ Individuals' } & \multicolumn{3}{c}{ awareness of partners' secret } \\
& relationship & \\
\hline HIV status & Yes & No & Total \\
\hline Women & & & \\
Positive & 53.7 & 48.1 & 430 \\
Negative & 43.3 & 51.9 & 422 \\
Total & 361 & 491 & 852 \\
$\%$ & 100 & 100 & 100 \\
Men & & & \\
Positive & 46.2 & 52.2 & 375 \\
Negative & 53.8 & 47.8 & 374 \\
Total & 264 & 485 & 749 \\
$\%$ & 100 & 100 & 100 \\
\hline \multicolumn{4}{c}{ Note. The source of data is from field survey, 2014 }
\end{tabular}

Fifty three percent women and $46.2 \%$ men who are aware of their partners' secret relationships are HIV positive (see Table 3).

Approximately $38 \%$ men and women who are married reported that they are aware of their partners' secret sexual relationships. While amongst those single, more men (48.1\%) reported being aware of their partners' involvement in secret relationships than the women (31\%). Whereas, approximately $67 \%$ of women who are in polygynous relationships (more than two wives) reported being aware of their husbands' secret relationships, only 38\% men reported the phenomenon amongst their partners. Despite the secret relationships, $60.2 \%$ women and $69.2 \%$ men in polygyny (two wives only) are yet to experience secret relationships in their unions (see Table 4).

Table 4. Percentage distribution of respondents by awareness of partners' secret relationship

\begin{tabular}{|c|c|c|c|c|}
\hline \multicolumn{5}{|c|}{$\begin{array}{l}\text { Number of sexual partners kept by the } \\
\text { respondents }\end{array}$} \\
\hline $\begin{array}{l}\text { Secret } \\
\text { relationship }\end{array}$ & One & Two & $\begin{array}{l}\text { More } \\
\text { than } 2\end{array}$ & $\mathbf{N}$ \\
\hline \multicolumn{5}{|l|}{ Women } \\
\hline Yes & 25.4 & 39.8 & 66.7 & 361 \\
\hline 0 & & 2 & 3 & 91 \\
\hline a & & & & 52 \\
\hline & & & & \\
\hline \multicolumn{5}{|l|}{ Men } \\
\hline Yes & .4 & 30.8 & 37.7 & 264 \\
\hline No & & 9.2 & 62 & 35 \\
\hline & & & $\angle 3$ & 49 \\
\hline & & 100 & 100 & \\
\hline \multicolumn{5}{|c|}{ Note. The source of data is from field survey, 2014} \\
\hline \multicolumn{5}{|c|}{$\begin{array}{l}\text { After controlling for the variables of } \\
\text { income, religion, condoms usage, love, desire for } \\
\text { pleasure and place to live; the common factor } \\
\text { significantly associated with secret partnership } \\
\text { for both men }(\mathrm{P}=.004 ; \mathrm{OR}=2.580 ; \mathrm{Cl}=1.350- \\
4.931) \text { and women }(\mathrm{P}<.001 ; \mathrm{OR}=3.668 ; \mathrm{Cl}= \\
1.908-7.604) \text { is partner being away from home } \\
\text { for at least a period of } 3 \text { months. While away } \\
\text { from home, such partners are motivated to } \\
\text { engage in secret relationships believing that they } \\
\text { may not be caught. Specifically, women who } \\
\text { seek for favours }(\mathrm{P}<.001 ; \mathrm{OR}=4.105 ; \mathrm{Cl}= \\
2.216-7.604) \text {, and who are in urban areas }(\mathrm{P}= \\
.04 \text {; OR }=0.615 ; \mathrm{Cl}=0.391-0.968) \text { are more } \\
\text { likely to have partners who are keeping secret } \\
\text { relationships. Men whose partners are engaged }\end{array}$} \\
\hline
\end{tabular}


in secret relationships are more likely to be students $(P=.04 ; O R=0.359 ; \mathrm{Cl}=0.139-0.938)$, civil servants $(P=.05 ; O R=0.377 ; \mathrm{Cl}=0.141$ 1.010), and those who have fewer number of children or no children with current partners $(P=$ $.04 ; \mathrm{OR}=1.186 ; \mathrm{Cl}=1.008-1.397$, see Tables 5 and 6).
For example, with reference to Urban-Ipusu, women in Rural-Ichongu, Rural-Ipusu and UrbanIchongu are more likely to experience secret relationships amongst their partners. While women with lower levels of education (no schooling, primary, secondary) are more likely to experience secret relationships amongst their

Table 5. Factors associated with women whose partners were keeping secret relationships

\begin{tabular}{|c|c|c|c|c|c|c|}
\hline \multirow{2}{*}{ Parameter } & \multirow[t]{2}{*}{ B } & \multicolumn{2}{|c|}{ Test of Hypothesis } & \multirow[t]{2}{*}{$\operatorname{Exp}(B)$} & \multicolumn{2}{|c|}{ 95\% Cl for $\operatorname{Exp}(\mathrm{B})$} \\
\hline & & df & Sig. & & Lower & Upper \\
\hline Secret wives & 1.958 & 1 & 0.419 & 7.086 & 0.062 & 8.149 \\
\hline Location (Rural-Ichongu) & -1.143 & 1 & 0.365 & 0.319 & 0.027 & 3.776 \\
\hline Rural-Ipusu & -0.352 & 1 & 0.777 & 0.704 & 0.062 & 7.993 \\
\hline Urban-Ichongu & -0.486 & 1 & 0.036 & 0.615 & 0.391 & 0.968 \\
\hline Sex (Male) & 1.429 & 1 & 0.302 & 4.175 & 0.277 & 63.017 \\
\hline \multicolumn{7}{|l|}{ Occupation } \\
\hline Farming & 1.438 & 1 & 0.219 & 4.214 & 0.425 & 41.803 \\
\hline Civil service & 1.420 & 1 & 0.235 & 4.138 & 0.396 & 43.212 \\
\hline Business & 1.118 & 1 & 0.337 & 3.060 & 0.312 & 29.996 \\
\hline Students & 1.445 & 1 & 0.218 & 4.242 & 0.425 & 42.355 \\
\hline Unemployed & 1.361 & 1 & 0.251 & 3.900 & 0.382 & 39.774 \\
\hline \multicolumn{7}{|l|}{ Education levels } \\
\hline No schooling & -0.445 & 1 & 0.223 & 0.641 & 0.313 & 1.311 \\
\hline Primary & -0.440 & 1 & 0.141 & 0.644 & 0.358 & 1.157 \\
\hline Secondary & -0.195 & 1 & 0.333 & 0.823 & 0.554 & 1.221 \\
\hline \multicolumn{7}{|l|}{ Family types } \\
\hline Monogamy & 0.184 & 1 & 0.613 & 1.202 & 0.589 & 2.454 \\
\hline $\begin{array}{l}\text { Polygamy } \\
\text { Need Favours }\end{array}$ & \multicolumn{5}{|c|}{ Need Favours } & 1.634 \\
\hline Strongly disagree & 1.412 & 1 & 0.000 & 4.105 & 2.216 & 7.604 \\
\hline Disagree & 1.156 & 1 & 0.000 & 3.179 & 1.791 & 5.641 \\
\hline Agree & 0.906 & 1 & 0.001 & 2.475 & 1.471 & 4.163 \\
\hline \multicolumn{7}{|l|}{ Partner stay away } \\
\hline Less than 3 months & 1.300 & 1 & 0.000 & 3.668 & 1.908 & 7.051 \\
\hline $\begin{array}{l}\text { Three or more but less than } 6 \\
\text { months }\end{array}$ & 0.849 & 1 & 0.016 & 2.336 & 1.175 & 4.645 \\
\hline $\begin{array}{l}\text { Six or more but less than } 9 \\
\text { months }\end{array}$ & 0.690 & 1 & 0.095 & 1.994 & 0.886 & 4.485 \\
\hline $\begin{array}{l}\text { Nine or more but less than } 1 \\
\text { Income per Month }\end{array}$ & 0.299 & 1 & 0.502 & 1.348 & 0.564 & 3.223 \\
\hline Less than $\mathrm{N} 25,000$ & 0.022 & 1 & 0.982 & 1.022 & 0.153 & 6.812 \\
\hline N25,000-N49,000 & -0.102 & 1 & 0.918 & 0.903 & 0.131 & 6.245 \\
\hline N50,000-N99,000 & -0.074 & 1 & 0.944 & 0.928 & 0.118 & 7.311 \\
\hline \multicolumn{7}{|l|}{ Age } \\
\hline $18-29$ years & 0.255 & 1 & 0.824 & 1.291 & 0.135 & 12.298 \\
\hline $30-44$ years & -0.121 & 1 & 0.916 & 0.886 & 0.094 & 8.389 \\
\hline 45-50 years & 0.614 & 1 & 0.597 & 1.847 & 0.190 & 17.978 \\
\hline Both Positive & -1.025 & 1 & 0.415 & 0.359 & 0.030 & 4.229 \\
\hline Positive/negative & -0.914 & 1 & 0.454 & 0.401 & 0.037 & 4.395 \\
\hline Positive/Don't know & -1.169 & 1 & 0.363 & 0.311 & 0.025 & 3.849 \\
\hline Negative/Don't know & -0.782 & 1 & 0.001 & 0.458 & 0.285 & 0.736 \\
\hline Children with current partner & 0.091 & 1 & 0.236 & 1.095 & 0.942 & 1.273 \\
\hline
\end{tabular}

The source of data is from field survey, 2014. The dependent variable is secret partnerships 
partners in comparison with those with tertiary education. Further, the longer the period women partners stay away from home for any reason, the more likely such women will experience secret relationships amongst their partners. In similar vein, women who are in need of favours are more likely to be in relationships where the partners are keeping secret relationships. Furthermore, with reference to HIV status, those who ae HIV positive are more likely to report that they have experienced secret relationships amongst their partners than those who are HIV negative.
With regard to men, those with lower levels of education and income are more likely to report that they have noticed their partners keeping secret relationships; being young, unemployed, student, or not having a child or fewer number of children with current partner are factors associated with men whose partners are keeping secret relationships. Further, men who are HIV positive are more likely to be in relationships where partners are engaged in secret relationships than those who are HIV negative (see Table 6). This is similar to what has been observed amongst women.

Table 6. Factors associated with men whose partners were keeping secret relationships

\begin{tabular}{|c|c|c|c|c|c|c|}
\hline \multirow[t]{2}{*}{ Variables } & \multirow[t]{2}{*}{ B } & \multicolumn{2}{|c|}{$\begin{array}{c}\text { Test of } \\
\text { hypothesis }\end{array}$} & \multirow[t]{2}{*}{$\begin{array}{l}\text { Exp } \\
\text { (B) }\end{array}$} & \multicolumn{2}{|c|}{$\begin{array}{c}\text { 95\% Confidence } \\
\text { interval for Exp (B) }\end{array}$} \\
\hline & & df & Sig. & & Lower & Upper \\
\hline \multicolumn{7}{|l|}{ Location } \\
\hline Rural-Ichongu & -1.155 & 1 & 0.332 & 0.315 & 0.031 & 3.249 \\
\hline Rural-Ipusu & -1.007 & 1 & 0.404 & 0.365 & 0.034 & 3.886 \\
\hline Urban-Ichongu & 0.390 & 1 & 0.112 & 1.476 & 0.913 & 2.388 \\
\hline \multicolumn{7}{|l|}{ Occupation } \\
\hline Farming & -0.462 & 1 & 0.342 & 0.630 & 0.243 & 1.634 \\
\hline Civil service & -0.976 & 1 & 0.052 & 0.377 & 0.141 & 1.010 \\
\hline Business & -0.669 & 1 & 0.158 & 0.512 & 0.203 & 1.295 \\
\hline Students & -1.025 & 1 & 0.036 & 0.359 & 0.137 & 0.938 \\
\hline Unemployed & -0.777 & 1 & 0.124 & 0.460 & 0.171 & 1.238 \\
\hline \multicolumn{7}{|l|}{ Education Levels } \\
\hline No schooling & -0.711 & 1 & 0.072 & 0.491 & 0.227 & 1.064 \\
\hline Primary & -0.096 & 1 & 0.781 & 0.909 & 0.462 & 1.785 \\
\hline $\begin{array}{l}\text { Secondary } \\
\text { Partner Stay away }\end{array}$ & -0.013 & 1 & 0.952 & 0.987 & 0.652 & 1.495 \\
\hline Less than 3 months & 0.948 & 1 & 0.004 & 2.580 & 1.350 & 4.931 \\
\hline Three or more but less than 6 months & 0.607 & 1 & 0.087 & 1.835 & 0.916 & 3.675 \\
\hline Six or more but less than 9 months & 0.799 & 1 & 0.098 & 2.222 & 0.862 & 5.730 \\
\hline \multirow{2}{*}{\multicolumn{7}{|c|}{ Income per Month }} \\
\hline & & & & & & \\
\hline Less than $\mathrm{N} 25,000$ & -1.124 & 1 & 0.122 & 0.325 & 0.078 & 1.351 \\
\hline $\mathrm{N} 25,000-\mathrm{N} 49,000$ & -1.191 & 1 & 0.099 & 0.304 & 0.074 & 1.249 \\
\hline N50,000-N99,000 & -0.927 & 1 & 0.214 & 0.396 & 0.092 & 1.705 \\
\hline \multicolumn{7}{|l|}{ Age } \\
\hline $18-29$ years & -1.489 & 1 & 0.277 & 0.226 & 0.015 & 3.310 \\
\hline $30-44$ years & -1.002 & 1 & 0.457 & 0.367 & 0.026 & 5.149 \\
\hline $45-50$ years & -1.257 & 1 & 0.349 & 0.284 & 0.020 & 3.952 \\
\hline \multicolumn{7}{|l|}{ Sexual webs (partners) HIV status } \\
\hline Both Positive & -1.536 & 1 & 0.208 & 0.215 & 0.020 & 2.349 \\
\hline Positive/negative & -1.387 & 1 & 0.238 & 0.250 & 0.025 & 2.496 \\
\hline Positive/Don't know & -1.492 & 1 & 0.238 & 0.225 & 0.019 & 2.685 \\
\hline Negative/Don't know & -0.468 & 1 & 0.051 & 0.627 & 0.392 & 1.001 \\
\hline Children with current partner & 0.171 & 1 & 0.040 & 1.186 & 1.008 & 1.397 \\
\hline
\end{tabular}


Further insight into the phenomenon of secret relationships has been enhanced by the reports from the in-depth interviews. The in-depth interviews were conducted on similar issues examined during the quantitative data collection. Several individuals were into the practice of keeping secret relationships, sometimes without the use of condoms, in spite of the health crisis, and adverse social implications it portent. The communities have laws and social norms that forbid these acts, however, the enforcement has been weak due to stigma and shame women may suffer during trial in the court. Many individuals see public scolding of offenders as denigration of relatives which may have negative social impact on them. However, in some instances, such offenders are punished. A respondent said:

Many people are still keeping multiple partners; I was also doing it before I got wedded in the church. But now I don't do it again, but many people are still doing it. Some people behave as dogs, despite the dangers involved in keeping girlfriends, they are doing it; they don't even use condoms. They are not cautious. We must revert back to the old values where people were punished for sleeping with unmarried ladies and married women. I feel there should be a law to punish such people (Male, Farmer, 54 years)

The evidence available points to the fact that sometimes either the man or the woman would flout the rules guiding marriage or co-habitation by engaging in secret relationship. However, the concern is bordered on the management of the issue when it is finally uncovered, because it may escalates hostilities inform of reprisals, separation or divorce. There are indications that sometimes the families of the partners involved would have to intervene. Below is a narrative that portrays the experience of one of the respondents:

Married people are not left out of this problem. Men leave their wives for other women, it is same with women. When a woman is aware of her husband's infidelity and complains, the man will get angry and threaten with violence. Those women outside sometimes ignite problems by insulting the wife. Women also leave their husbands for other men, and when they know and complain, the woman will carry their things and leave for their parents' home. Most of these behaviours are reprisals. (Female, Housewife, 32 years).

Furthermore, the effects of secret multiple partnership are complex and dynamic. It can trigger crisis in marriages that impact negatively on the training of the children. The problems are obvious and germane to the uncontrollable emotional outburst of partners that render the management of the family affairs ineffective. Where there is divorce or separation, the partners are further exposed to risk of HIV infection through new partnerships. Again, another participant provides information on the issue in the following words:

The problem of infidelity is high here. My brother has left his wife for other women, and the wife has separated from him now. There are many women I know that are married but they have other men, if it is something to call names, I would have mention their names. They have problems, they are always quarrelling and that has affected the children in terms of discipline. The children are divided either on the side of the mother or the father. They lack proper discipline. People should help in enlightening families (Male, farmer, 31 years).

The cultural norms of associating polygamous marriages with wealth and social status have made several individuals favourably disposed to multiple relationships. They point out that, as the tongue would like to taste varieties of food, so, it is with some men who would like to experience other relationships rather than keeping to one partner. Similarly, some participants have likened the engagement of women in secret relationships to the natural disposition of some primates such as monkeys to steal food in the fields, in the absence of the owners. The issue is captured in the words of a male participant who has reported the matter in the following words:

Some people here are having several partners. There is a saying that a monkey cannot stop stealing food, so the women steal by having secret relationships. For the men, they say eating one food always is not good because it reduces appetite. So some people are having many partners (Male, student; 27 years). 


\section{CONCLUSION}

The phenomenon of multiple partnerships has been documented [See 10,11,28,15,16]. However, gaps exist in knowledge on correlates of secret multiple partnership, sex differentials and HIV risk amongst stable relationships in Tiv land. Multiple partnerships can exist amongst those who are married, single, widowed, divorced, separated, and cohabiting as observed in this study. Whereas, it portend health and social crisis on part of the individuals involved, it is more severe on those who are married. It sometimes triggers emotional outburst that defiles all forms of negotiations leading to disruption of family cohesion. The resultant effects are divorce, risk of HIV infections through new partnership formations, and poor management of family affairs including the training of children,

In sum, men keep more secret partners than the women, given that the men have enhanced sexual capacity (favourable individual, family and structural factors) than the women. However, some men with lower levels of education and income, and those who do not have children with their current partners are in relationships with women who are keeping secret relationships. Whereas married men are more likely to engage in secret multiple partnerships than their female counterpart; the women who are single engage in secret multiple relationships more than their male counterpart. Partners staying away from home for a period of at least 3 months is a risk factor for secret relationship and HIV infection for both men and women in stable relationships. In spite of the secret relationships, there are those in polygyny that have not admitted secret partners into their unions.

It can be argued that sex work is a type of concurrency, hence it is practiced amongst multiple concurrent partners. Such sexual behaviours have been observed to be highly risky especially where condom usage is low. Sex work has attracted considerable attention [1318]. Another type of multiple partnerships could be serial partnerships with short gaps between them, it may constitute similar risk such as posed by multiple concurrent partners, since a recently infected person may expose a new partner to HIVISTI while transmission probabilities are highest [19]. Furthermore, another type is the secret multiple partnerships which exist amongst individuals who have primary partners as observed in this study.
The multiple relationships that exist amongst sex workers have been given considerable attention by scholars and health providers. However, serial multiple relationships within short gaps and the secret multiple partnerships are yet to be adequately documented. And in the face of low condom use as observed in this study (only $37 \%$ respondents used condoms regularly in the last six months before the interviews), secret multiple partnerships constitute high risk of HIV infection. The serial and secret multiple partnerships might be the types of concurrency, implicitly implicated for aiding the spread of HIV in Africa $[3,4,9,10$, $11,28]$.

It is also interesting to note that some polygynists in the study are yet to open their unions to secret relationships. They are in benign multiple relationships if one of the partners was not infected with HIV before the union. This is similar to the observations of Reiners and Watkins [12] who opined that benign concurrency relationships are less likely to aid the spread of HIV in Africa.

Understanding the correlates of secret multiple partnerships and sex differentials examined in this study would assist in providing information on the risk of HIV infections amongst partners. Such knowledge would be of considerable benefits for developing strategies for HIV prevention through secret multiple sexual relationships that are shrouded in unsafe sexual practices, especially in Nigeria and Africa at large where secret multiple partnerships are common instable relationships but condom use is low.

\section{END NOTE}

a Sample size determination was guided by the formula

$$
B=x^{2} p q / d^{2}
$$

$X=$ standard normal deviation at $95 \%$, which is 1.96;

$\mathrm{p}=$ proportion of partners in sexual exclusivity relationship; but since search in literature has not yielded that proportion from study of this nature, $\mathrm{p}$ will be considered to be $50 \%$, which is 0.5 (equally likely events).

$$
\begin{aligned}
& q=1-p=0.5 ; d=0.05 \text { level of precision } \\
& B=1.96^{2} \times 0.5 \times 0.5 / 0.05^{2}=384
\end{aligned}
$$


More than 384 respondents were selected from each of the four locations as follows:

Urban-Ipusu - 411 (183 males, 228 females); Urban-Ichongu - 394 (190 males, 204 females); Rural-Ipusu - 396 (169 males, 227 females); Rural-lchongu - 400 (207 males, 193 females). It brings the total numbers of respondent to 160 .

\section{CONSENT}

Both the consent to participate in the study and for the publication of the findings was obtained from the participants using ACU consent form before data collection activities.

\section{ETHICAL APPROVAL}

As per international standard or university standard, written approval of Ethics committee has been collected and preserved by the author.

\section{ACKNOWLEDGEMENT}

The author acknowledge the financial support from Australian Catholic University and the contribution of Prof. Timothy Scrase and Dr. Haydn Aarons (my supervisors) to HIV and Sexual Behaviour research in Nigeria. I also appreciate Shikaan, Tever; Amokaha Samuel; Ali, Jennifer; Asom, Nicholas; Kough, Mbachie; Nyamshar, Seember; Akpii, Peter; Ngiyev, Godwin; kohol, Gladys; lortyom, Benedict and Faga, Emmanuel who helped with data collection. Others are Tarhembe, Joseph; Dyegh, Cletus; Sati, Saakaan, and Anchongu, Emmanuel. Doris Timiun helped with data entry.

\section{COMPETING INTEREST}

Author has declared that no competing interests exist.

\section{REFERENCES}

1. Halperin DT, Epstein H. Concurrent sexual partnerships help to explain Africa's high HIV prevalence: Implications for prevention. The Lancet. 2004;364(9428):46.

2. Badcock PB, Smith AM, Richters J, Rissel $C$, de Visser RO, Simpson JM, et al. Characteristics of heterosexual regular relationships among a representative sample of adults: The second Australian study of health and relationships. Sexual Health. 2014;11(5):427-38.

3. Watts $\mathrm{CH}$, May RM. The influence of concurrent partnerships on the dynamics of HIVIAIDS. Mathematical Biosciences. 1992;108(1):89-104.

4. Hudson CP. Concurrent partnerships could cause AIDS epidemics. International Journal of STD \& AIDS. 1993;4(5):249-53.

5. Paz-Bailey G, Morales-Miranda S, Jacobson JO, Gupta SK, Sabin K, Mendoza $S$, et al. High rates of STD and sexual risk behaviors among Garifunas in Honduras. Journal of Acquired Immune Deficiency Syndromes. 2009;51(Suppl1): S26-34.

6. Mah TL, Halperin DT. The evidence for the role of concurrent partnerships in Africa's HIV epidemics: A response to Lurie and Rosenthal. AIDS and Behavior. 2009; 14(1):25-8.

7. Wellings $\mathrm{K}$, Collumbien $\mathrm{M}$, Slaymaker $\mathrm{E}$, Singh S, Hodges Z, Patel D, et al. Sexual behaviour in context: A global perspective. Lancet (London, England). 2006; 368(9548):1706-28.

8. Kretzschmar $M$, White RG, Caraël $M$. Concurrency is more complex than it seems. AIDS (London, England). 2010; 24(2):313-5.

9. Kretzschmar M, Morris M. Measures of concurrency in networks and the spread of infectious disease. Mathematical Biosciences. 1996;133(2):165-95.

10. Morris $M$, Kretzschmar M. Concurrent partnerships and the spread of HIV. Aids. 1997;11(5):641-8.

11. Morris $M$, Kretzschmar M. A microsimulation study of the effect of concurrent partnerships on the spread of HIV in Uganda. Mathematical Population Studies. 2000;8(2):109-33.

12. Reniers G, Watkins S. Polygyny and the spread of HIV in sub-Saharan Africa: A case of benign concurrency. Aids. 2010; 24(2):299-307.

13. de Visser R. One size fits all? Promoting condom use for sexually transmitted infection prevention among heterosexual young adults. Health education research. 2005;20(5):557-66.

14. Stephenson $\mathrm{R}$, Winter A, Elfstrom $M$. Community environments shaping transactional sex among sexually active men in Malawi, Nigeria, and Tanzania. AIDS Care. 2013:25(6):784-92. 
15. Fitzgerald-Husek $A$, Martiniuk $A L$, Hinchcliff R, Aochamus CE, Lee RB. "I do what I have to do to survive": An investigation into the perceptions, experiences and economic considerations of women engaged in sex work in Northern Namibia. BMC Womens Health. 2011; 11(35):1472-87.

16. MacLachlan E, Neema S, Luyirika E, Ssali $F$, Juncker $M$, Rwabukwali $C$, et al. Women, economic hardship and the path of survival: HIVIAIDS risk behavior among women receiving HIVIAIDS treatment in Uganda. AIDS Care. 2009;21(3):355-67.

17. Weiser SD, Leiter K, Bangsberg DR, Butler LM, Percy-de Korte F, Hlanze Z, et al. Food insufficiency is associated with highrisk sexual behavior among women in Botswana and Swaziland. PLoS Med. 2007;4(10):e260.

18. Hunter M. The materiality of everyday sex: thinking beyond 'prostitution'. African Studies. 2002;61(1):99-120.

19. Mercer $\mathrm{CH}$, Aicken $\mathrm{CR}$, Tanton C, Estcourt CS, Brook MG, Keane $F$, et al. Serial monogamy and biologic concurrency: Measurement of the gaps between sexual partners to inform targeted strategies. American Journal of Epidemiology. 2013; 178(2):249-59.

20. Gargallo, F. Garifuna: A culture of women and men. In: Palacio J, editor. The Garifuna: A nation across borders essays in social anthropology. Benque Viejo Del Carmen: Cubola Productions. 2005;13758.

21. Grieb SM. Gender, transnational migration, and HIV risk among the Garinagu of Honduras and New York City [Internet]. University of Florida; 2009.

Available:http://etd.fcla.edu/UF/UFE00411 71/ dolwickgrieb s.pdf

(Cited 6 Dec 2013)
22. Kerns V. Female control of sexuality: Garifuna women at middle age. In: Kerns $\mathrm{V}$, Brown JK, editors. In her prime: New views of middle-aged women. Urbana: University of Illinois Press. 1992;95111.

23. Dodoo FN, Zulu EM, Ezeh AC. Urban-rural differences in the socioeconomic deprivation--sexual behavior link in Kenya. Social Science \& Medicine. 2007;64(5): 1019-31.

24. Mah TL, Maughan-Brown B. Social and cultural contexts of concurrency in a township in Cape Town, South Africa. Culture, Health \& Sexuality. 2012; 15(2):135-47.

25. Jewkes R, Morrell R. Gender and sexuality: Emerging perspectives from the heterosexual epidemic in South Africa and implications for HIV risk and prevention. Journal of the International AIDS Society. 2010;13:6.

26 National agency for the control of AIDS (NACA). Federal Republic of Nigeria. Global AIDS response: Country Progress Report (Nigeria GARPR), Abuja, Nigeria; 2014.

Available:www.unaids.org/.../knowyourresp onse/countryprogressreports/2012coun (Cited 20/4/2015)

27 Timiun GA. Sexual webs model for the examination of unsafe sexual behaviours and the spread of sexually transmitted diseases including HIVIAIDS. Asian Social Science. 2012;8:7.

DOI: $10.5539 / a s s . v 8 n 7 p 11$

28. Mah TL, Shelton JD. Concurrency revisited: Increasing and compelling epidemiological evidence. Journal of the International AIDS Society. 2011;14: 33-33.

(c) 2017 Aondohemba; This is an Open Access article distributed under the terms of the Creative Commons Attribution License (http://creativecommons.org/licenses/by/4.0), which permits unrestricted use, distribution, and reproduction in any medium, provided the original work is properly cited.

Peer-review history:

The peer review history for this paper can be accessed here: http://sciencedomain.org/review-history/19997 